\title{
PREDISPOSING AND REINFORCING FACTORS IN PATIENTS WITH BREAST CANCER IN SAMARINDA, EAST KALIMANTAN
}

\author{
Lia Kurniasari, Aji Mohammad Irfannur, Ayu Mardiana, \\ Elvi Natalia, Erlinda Rara Sulviana, Nur Ainun Jariah
}

Public Health Study Program, Faculty of Health and Pharmacy, Muhammadiyah University of East Kalimantan

\begin{abstract}
Background: Breast Cancer can be disturbed for health and psychological. Breast cancer has reached the second deadly disease. Causative factors include age, marital status, use of hormonal contraception, history of breastfeeding, family history, family support, self-acceptance, stress levels, and breast selfexam knowledge. This study aimed to investigate the factors predisposing and reinforcing breast cancer incidence in Samarinda, East Kalimantan.

Subject and Method: This was a cross-sectional study conducted in Samarinda, East Kalimantan. A total of 216 samples by using accidental sampling were selected for this study. The dependent variable was the incidence of breast cancer. The independent variables were education, marital status, use of hormonal contraception, history of breastfeeding, family history, family support, self-acceptance, stress levels, and breast self-exam knowledge. The data were collected by questionnaire via a google form. Data analysis using Chi-Square test.

Results: The significant risk factors of breast cancer were education, marital status, hormonal contraception, history of breastfeeding, stress conditions, and self-acceptance. Family history and family support, and breast self-exam knowledge were insignificantly associate with the risk of breast cancer.

Conclusion: The significant risk factors of breast cancer are education, marital status, hormonal contraception, history of breastfeeding, stress conditions, and self-acceptance. Family history and family support, and breast self-exam knowledge are insignificantly associate with the risk of breast cancer.
\end{abstract}

Keywords: Breast cancer, predisposing, reinforcing.

\section{Correspondence:}

Lia Kurniasari. Public Health Study Program, Faculty of Health and Pharmacy, Muhammadiyah University of East Kalimantan, Indonesia. Email: liakesmas@um-kt.ac.id. Mobile: +6285231669773.

\section{BACKGROUND}

Breast cancer is a disease that contributes to high mortality rates worldwide. Breast cancer is a condition in which the body's cells divide out of control, which eventually becomes malignant. The spread of breast cancer or metastasis, can be through the bloodstream. Metastasis complications can worsen a patient's health status until it leads to death (Ghoncheh et al., 2016).

Cancer threatens health both physically and psychologically and can even cause death. A survey conducted by the World
Health Organization in 2014 stated that in the world breast cancer is one of them with a total of 52,1000 deaths and affects more than 1.5 million women each year while the mortality data or the Cancer Mortality Profile showed the mortality rate of breast cancer with a percentage of $21.4 \%$. Breast cancer had reached the second-order of deadly diseases (Dewi, 2017).

Cancer is a disease that causes the second-highest number of deaths globally, an estimated 9.6 million people died in the world due to cancer incidence in 2018.

The 7th International Conference on Public Health

Solo, Indonesia, November 18-19, $2020 \mid 92$

https://doi.org/10.26911/the7thicph-FP.01.11 
Generally, breast cancer incidence reached a case, and the red incidence rate reached 58,265 cases and around $16.7 \%$ of the total cancer cases as a whole (Setyowibowo et al., 2020). It was estimated that there were 100 new cases per 100,000 population each year. It means that out of 237 million people, there were around 237,000 breast cancer sufferers each year. Therefore, the information also showed that cancer prevalence increases with age (Setyowibowo et al., 2020).

The prevalence of cancer in Indonesia ranges from 1.4 per 1,000 population. Data from the international agency for cancer research showed that the highest incidence rate of breast cancer is in Australia, with 94.2\%, in Western Europe 92.6\%, and 90.1\% in Northern Europe. The highest breast cancer is the rate in Asia, including Indonesia. Indonesia is one of the countries with the highest incidence and death rates in Southeast Asia, with $19.8 \%$ of new cases and $12.75 \%$ of deaths due to breast cancer (Cancer: A World of Difference Breast Cancer: A World, 2020).

The East Kalimantan Provincial Health Office stated that the number of people with breast cancer was 179 in 2014 and 424 cases in 2015. It can be said that there was a significant increase in breast cancer cases from 2014 as much as 56.28\%, and a death rate of $36.85 \%$ (DKK Samarinda, 2017). There has been an increase in the incidence of breast cancer from year to year. The purpose of this study was to look at various driving factors in the incidence of breast cancer ranging from analyzing the relationship between occupation, level of education, marital status, use of hormonal contraceptives, history of exclusive breastfeeding, family history of cancer patients, family support of people with cancer, stress levels, self acceptance, BPJS ownership, and knowledge aware of breast cancer incidence in Samarinda, East Kalimantan.

\section{SUBJECTS AND METHOD}

\section{Study Design}

This was a cross-sectional study conducted in Samarinda, East Kalimantan.

\section{Population and Sample}

A total of 216 samples by using accidental sampling were selected for this study. The sample calculation used a sample size formula, with Lemeshow. The inclusion criteria were women aged 14 to 65 years living in East Kalimantan who filled in consent and online questionnaire. The exclusion criteria were women who filled out the questionnaire but did not complete the answer. The validity test had been conducted first.

\section{Study Variables}

The dependent variable was the incidence of breast cancer. The independent variables were education, marital status, use of hormonal contraception, history of breastfeeding, family history, family support, self-acceptance, stress levels, and breast self-exam knowledge.

\section{Study Instruments}

The study was conducted by sharing Google forms which are disseminated through social media.

\section{Data Analysis}

The data were collected by questionnaire via a google form. Data analysis using Chi-Square test.

\section{RESULTS}

$\overline{\text { Table } 1 \text { showed several predisposing factors }}$ and reinforcing the incidence of breast cancer. Factors which indicated the significant relationship with breast cancer incidence were education level, marital status, hormonal contraception, history of breastfeeding, stress conditions, and self-acceptance, where $\mathrm{p}$ value below 0.050 . Meanwhile, there was no significant relationship in the variables of family history, family support, and BSE knowledge with the incidence of breast cancer, where $\mathrm{p}$ value $\geq 0.050$.

The 7th International Conference on Public Health Solo, Indonesia, November 18-19, $2020 \mid 93$ https://doi.org/10.26911/the7thicph-FP.01.11 
Table 1. Factors predisposing and reinforcing incidence of breast cancer (chisquare)

\begin{tabular}{|c|c|c|c|c|c|c|}
\hline \multirow{2}{*}{ Variables } & \multicolumn{2}{|c|}{$\begin{array}{c}\text { Cancer } \\
\text { Patients }\end{array}$} & \multirow{2}{*}{$\mathbf{O R}$} & \multicolumn{2}{|c|}{$95 \%$ CI } & \multirow{2}{*}{$\mathbf{p}$} \\
\hline & Yes & No & & $\begin{array}{c}\text { Lower } \\
\text { Limit }\end{array}$ & $\begin{array}{l}\text { Upper } \\
\text { Limit }\end{array}$ & \\
\hline \multicolumn{7}{|l|}{ Level of education } \\
\hline Low & 65 & 107 & \multirow{2}{*}{2.07} & \multirow{2}{*}{0.96} & \multirow{2}{*}{4.46} & \multirow{2}{*}{0.060} \\
\hline $\begin{array}{l}\text { High } \\
\text { Marital status }\end{array}$ & 10 & 34 & & & & \\
\hline Unmarried & 17 & 110 & \multirow[b]{2}{*}{0.08} & \multirow[b]{2}{*}{0.04} & \multirow[b]{2}{*}{0.16} & \multirow[b]{2}{*}{$<0.001$} \\
\hline $\begin{array}{l}\text { Married and never } \\
\text { married }\end{array}$ & 58 & 31 & & & & \\
\hline \multicolumn{7}{|c|}{ Hormonal contraceptives } \\
\hline $\begin{array}{l}\text { Hormonal } \\
\text { Non-hormonal }\end{array}$ & $\begin{array}{l}43 \\
32\end{array}$ & $\begin{array}{c}23 \\
118\end{array}$ & \multirow[t]{2}{*}{6.89} & \multirow[t]{2}{*}{3.64} & \multirow[t]{2}{*}{13.07} & \multirow[t]{2}{*}{$<0.001$} \\
\hline History of breast & & & & & & \\
\hline $\begin{array}{l}\text { Yes } \\
\text { No }\end{array}$ & $\begin{array}{l}29 \\
46\end{array}$ & $\begin{array}{c}28 \\
113\end{array}$ & \multirow[t]{2}{*}{2.54} & \multirow[t]{2}{*}{1.37} & \multirow[t]{2}{*}{4.74} & \multirow[t]{2}{*}{29} \\
\hline Family history & & & & & & \\
\hline $\begin{array}{l}\text { Yes } \\
\text { No }\end{array}$ & $\begin{array}{l}18 \\
57\end{array}$ & $\begin{array}{c}33 \\
108\end{array}$ & \multirow[t]{2}{*}{1.03} & \multirow[t]{2}{*}{0.54} & \multirow[t]{2}{*}{2.00} & \multirow[t]{2}{*}{18} \\
\hline Stress conditions & & & & & & \\
\hline $\begin{array}{l}\text { Stress light } \\
\text { Severe stress }\end{array}$ & $\begin{array}{l}35 \\
40\end{array}$ & $\begin{array}{l}84 \\
57\end{array}$ & \multirow[t]{2}{*}{0.59} & \multirow[t]{2}{*}{0.34} & \multirow[t]{2}{*}{1.04} & \multirow[t]{2}{*}{0.072} \\
\hline Self-acceptance & & & & & & \\
\hline $\begin{array}{l}\text { Yes } \\
\text { Not Yet / No }\end{array}$ & $\begin{array}{l}38 \\
37\end{array}$ & $\begin{array}{l}50 \\
91\end{array}$ & \multirow[t]{2}{*}{1.87} & \multirow[t]{2}{*}{1.06} & \multirow[t]{2}{*}{$3 \cdot 30$} & \multirow[t]{2}{*}{0.033} \\
\hline Family support & & & & & & \\
\hline $\begin{array}{l}\text { Yes } \\
\text { No }\end{array}$ & $\begin{array}{c}71 \\
4\end{array}$ & $\begin{array}{c}136 \\
5\end{array}$ & 0.65 & 0.17 & 2.51 & 0.545 \\
\hline Knowledge BSE & & & & & & \\
\hline $\begin{array}{l}\text { Know } \\
\text { Don't know }\end{array}$ & $\begin{array}{l}45 \\
30\end{array}$ & $\begin{array}{l}83 \\
58\end{array}$ & 1.05 & 0.59 & 1.86 & 0.875 \\
\hline
\end{tabular}

\section{DISCUSSION}

This study showed a relationship between the level of education and the incidence of breast cancer. The level of education of a person at the beginning of a person is able to know more things (Indrati, 2005). According to Notoatmodjo (2010), the higher a person's education, the easier it would be to obtain information that was related and could be applied to himself. People with a high education level will find it easier to get information either directly or find new sources of information from anywhere.
All information today is very easy to find and get only through the grip of a cell phone. Information related to women's health, especially breast cancer, needs to pay more attention to themselves. As a preventive step, at least initial screening in the house needs to be carried out.

The level of education will also affect a person's attitude in carrying out health behaviors every day, such as diet and contraception (Djauharoh, 2015). Women need to routinely perform breast massage while bathing then cross-checks during the initial

The 7th International Conference on Public Health Solo, Indonesia, November 18-19, $2020 \mid 94$ https://doi.org/10.26911/the7thicph-FP.01.11 
menstruation until menstruation is complete whether there is a lump. This will be easier for people with more knowledge (Susanti, 2020).

Marital status in this study showed a relationship between marital status and the incidence of breast cancer. Based on Indrati (2005) research, the cancer incidence is more in women with unmarried status. Unmarried women do not have the hormone estrogen as a hormone that supports pregnancy and breastfeeding. Without estrogen hormone, there is no balance in the body. But other studies suggested a relationship between marital status and breast cancer incidence.

In a marriage, a woman will certainly experience a new life cycle which is pregnancy and breastfeeding. After that, a woman will usually use contraceptives to adjust the length of the next pregnancy. Therefore, this will be a risk factor for breast cancer.

Women who could not give exclusive breastfeeding to their children are also a risk factor for breast cancer. The hormones estrogen, and prolactin are not secreted maximally. Therefore, this will be the forerunner of a woman's breast cancer causes (Septianingrum and Afiyah, 2018).

Nissa (2017) stated that the use of hormonal contraceptives would increase the risk of cancer events related to hormonal factors, especially in breast cancer and cervical cancer, especially in oral contraceptives or birth control pills. Birth control pills contain progesterone which will affect the function of the estrogen hormone. Hormonal use can cause an increase in exposure to the hormone estrogen in the body. Exposure to the increased estrogen hormone will trigger abnormal cell growth in the breast gland, eventually leading to cancer (Suryanti, 2017).

Latent cancer cells or estrogen receptors Alfa have a role and development in the breast glands when excessive estrogen results in genetic changes and triggers abnormal development or proliferation (Hasnita, 2019). Other research will also result in estrogen receptors so that uncontrolled mitotic processes of breast gland stem cells will occur, which will eventually lead to breast cancer.

According to the National Cancer Institute, the use of hormonal contraceptives, especially oral birth control types, will increase cancer risk $\geq 10$ years old than those who never used hormonal contraception, including those under 10. The length of time using hormonal contraceptives was likely to increase 1.52 times the risk of breast cancer since the use of hormonal contraception for 4 years (Wahidin, 2018).

Sukmayenti (2019) found that nonbreastfeeding mothers had a risk of 5.6 compared to breastfeeding ones, with $\mathrm{p}=$ o.033. Indrati (2005) also stated that breast cancer risk increases with a history of breastfeeding $<2$ years. There will be a decrease in estrogen level and release of cancer-triggering substances during breastfeeding, so the longer the protective effect against cancer will be. In the study of Liu et al. (2010) stated that the risk of cancer was reduced by $4 \%$ for breastfeeding for 12 months. Because during breastfeeding there is a delay in menstruation.

Liu et al. (2010) study showed a positive family history is the biggest risk factor for breast cancer in women. Women whose family has breast cancer are twice as likely to develop breast cancer. Women with 2 breast cancer patients in the family will have a 14fold greater risk of developing breast cancer. Meanwhile, 20\% of women who have breast cancer have a long family history of people with breast cancer (Meylissa, 2018).

The risk of developing breast cancer can be doubled if one of the nuclear family members is affected by breast cancer. According to

The 7th International Conference on Public Health Solo, Indonesia, November 18-19, $2020 \mid 95$ https://doi.org/10.26911/the7thicph-FP.01.11 
Suyatno (2014), a woman with a first-degree family history, such as her mothers and siblings, have four to six times the risk of women without a family history of breast cancer. This could have happened due to mutations in the BRCA1 and BRCA2 genes.

In this study, the results showed a relationship between stress conditions and breast cancer incidence in Samarinda City. According to the theory, one of the causes of various problems is triggered by stress levels. Someone stress becomes one of the factors that are difficult to measure and affected adversely. The impact of someone experienceing stress could cause various problems in one's health, including a breast cancer patient.

There is an emotional upheaval in breast cancer patients between refusing and being forced to accept it. But the patients cannot drag on in this stressful condition as stress conditions will worsen the situation. Women with breast cancer also experience an enormous burden of thoughts, including financial readiness for treatment, and tasks and responsibilities as housewives/ mothers.

Assistance and understanding from the closest family are needed to help stress management of the breast cancer patient. The research revealed that stress conditions strongly related to diseases. Therefore, not only for breast cancer patients but also for all the patients from other diseases need to manage stress to receive a better treatment effect.

This study results showed a relationship between self-acceptance and the incidence of breast cancer in women. At the time of diagnosis, it would have been shocking that there were many thoughts in women who tried to ask themselves why I was exposed to it. Where did this disease come from? What have I done so far so I can get this disease? This condition is closely related to stress management as one of the variables measured in this study.

Self-acceptance will be difficult to do for breast cancer patients. Therefore, by managing stress, women who are positive for breast cancer will be more able to accept it sincerely.

All stages of treatment will be able to pass properly. Family members also need to accompany, encourage, and be at the breast cancer patient's side to not feel alone in undergoing this treatment process. It will help the self-acceptance of these breast cancer patients to live a better life in the future. Other research also stated that the self-acceptance factor is closely related to family support, social support, and financial support. Those factors are strongly related to the outcomes of the treatment stages.

Those are the efforts that can be done to increase knowledge, especially for women to understand further and conduct an initial screening of precursors to cancer. Various studies showed a relationship between maternal knowledge and efforts to detect breast cancer through breast self-exam (BSE) ( $\mathrm{p}=$ o.020). Another study conducted by Handayani (2008) stated a relationship between the behavior of early adult women in carrying out BSE checks.

According to Notoadmojo (2007), a person's behavior regarding health is determined by knowledge, attitudes, and beliefs. Knowledge is also necessary to take action easily. In 2006, only about $25 \%$ to $30 \%$ of women had BSE checks. (Smeltzer, 2006).

Based on the study, it was concluded that several predisposing and reinforcing factors influenced the incidence of breast cancer in Samarinda City. Good knowledge of preventive measures, self-acceptance, stress management, and family support became important factors to women diagnosed with

The 7th International Conference on Public Health

Solo, Indonesia, November 18-19, $2020 \mid 96$

https://doi.org/10.26911/the7thicph-FP.01.11 
breast cancer Good knowledge of preventive measures will make a woman pay more at-

\section{REFERENCES}

Cancer: A World of Differenc Breast Cancer:

A World: (2020). 343(6178), 14521453 .

Djauharoh, H. (2015). Factors related to the use of long-term contraception method (a study on contraceptive users in kabu. Jurnal Manajemen Kesehatan Indonesia, 03(01): 1-7.

Ghoncheh M, Pournamdar Z, Salehiniya H (2016). Incidence and mortality and epidemiology of breast cancer in the world. Asian Pac J Cancer Prev, 17, 4346. https://doi.org/10.7314-/APJCP$.2016 .17 . \mathrm{S} 3.43$

Hasnita Y, Harahap WA, Defrin (2019). Artikel penelitian pengaruh faktor risiko hormonal pada pasien kanker di RSUP.Dr.M.Djamil Padang. Jurnal Kesehatan Andalas, 8(3), 522-528. doi: https://doi.org/10.25077/jka.v8i3.1037

Indrati R, Setiawan H, Handojo D (2005). Faktor faktor risiko yang berpengaruh terhadap kejadian kanker payudara wanita. 1-8. Available: https://core.ac.uk/download/files/379/11715083.pd f.

Liu T, Gatsonis CA, Baylin A, Buka SL (2010). Prenatal exposure to cigarette smoke and benign breast disease. Epidemiology, 21(5), 736-743. doi: https://doi.org/10.1097/EDE.obo13e3181e9c 118.

Dewi M (2017). Sebaran kanker indonesia. Indonesian Journal of Cancer, 11(1). (tidak ada disitasi)

Meylissa M, Sanusi SR, Ashar T (2018).

Relationship of family disease human relationship with breast cancer diagnosis in general hospital regional $\mathrm{dr}$. Zainoel abidin banda aceh in 2017. tention to her health, and a healthy lifestyle will be easier to implement.

IOSR JHSS, 23(1), 37-41. doi: https://doi.org/10.9790/o837-2301063741.

Nissa PAE, Widjajanegara H, Purbaningsih W (2017). Kontrasepsi hormonal sebagai faktor risiko kanker payudara di rsud al-ihsan bandung. Bandung Meeting on Global Medicine \& Health (BaMGMH), 1(1), 112-119.

Notoatmodjo SP (2010). Pendiddikan dan perilaku kesehatan. Jakarta: Rineka Cipta.

Samarinda, DKK (2019). Laporan Kasus Kanker Payudara.

Septianingrum Y, Afiyah RK (2018). Penyuluhan deteksi dini kanker payudara di pondok pesantren qomaruddin bungah gresik. Community Development Journal, 1(2): 67-71. doi: https://doi.org/10.33086/cdj.v1i2.348.

Setyowibowo H, et al (2020). A self-help intervention for reducing time to diagnosis in Indonesian women with breast cancer symptoms. Psychoonco-logy, (29(4): 1-7. https://doi.org/-10.1002/pon.5316.

Sukmayenti, Sari N (2019). Analisis determinan kanker payudara pada wanita di Rsup Dr. M. Djamil Padang tahun 2018. Jurnal Kesehatan, 1(1): 77-86. Retrieved from http://journals.ums.ac.id/index.php/JK/article/view/7668.

Suryanti (2017). Jurnal ilmiah kesehatan media husada. Hubungan Peran Suami Terhadap Pemilihan Jenis Alat Kontrasepsi KB Pada Ibu Di Kelurahan Kebonsari Kabupaten Jember, 02, 111118.

Susanti R, Damayanti DS (2020). Observation on breast self-examination (BSE) for early detection of breast cancer in students at health. Journal Research Midwifery Politeknik Tegal, o9(01),

The 7th International Conference on Public Health Solo, Indonesia, November 18-19, $2020 \mid 97$ https://doi.org/10.26911/the7thicph-FP.01.11 
29-34. https://doi.org/10.30591/siklus.v9i1.1677.g1078

Wahidin M, Djuwita R, Adisasmita A (2018). Oral contraceptive and breast cancer risks: A case control study in six referral hospitals in Indonesia. Asian Pacific Journal of Cancer Prevention, 19(8), 2199-2203. https://doi.org/10.22034/APJCP.2018.19.8.2199. 